\title{
Extraction Of Cornhusk Fibres For Textile Usages
}

\author{
Archana Jain ${ }^{1}$,Deepali Rastogi ${ }^{2}$, Bhawana Chanana $^{3}$,M.S.Parmar ${ }^{4}$, Aditi Dhama ${ }^{5}$ \\ ${ }^{I}$ (Research Scholar, Department Of Fabric \& Apparel Science, Lady Irwin College, Delhi University, India) \\ 2, (Associate Professor, Department Of Fabric \& Apparel Science, Lady Irwin College, Delhi University, India) \\ 3 (Professor And Head, Amity School Of Fashion Design And Technology, Mumbai) \\ ${ }^{4}$ (Professor \& Joint Director, Northern India Textile Research Association (NITRA) Ghaziabad, India) \\ ${ }^{5}$ (Student, M.Sc. (Fabric \& Apparel Science),Lady Irwin College, Delhi University, India)
}

\begin{abstract}
Cornhusk fibres were extracted with step-wise treatment using alkali, enzyme and bleach. The extracted fibres were analysed for various physico-chemical parameters. The alkali treatment was optimized with respect to concentration of sodium hydroxide, temperature and time of treatment. The extracted fibres as the fibres obtained in optimum conditions had strength and fineness as $1.59 \mathrm{~g} /$ denier and 130 denier respectively. The fibres after final bleaching treatment had bundle strength of $1.33 \mathrm{~g} /$ denier and fineness of 86 denier. Bleached cornhusk fibres were composed of $76 \%$ cellulose, $11.43 \%$ hemicelluloses, $7.5 \%$ lignin, $0.25 \%$ and $0.34 \%$ ash content. Finally, fibres were assessed for their physio-chemical properties and it was found that the extracted fibres could be used for various textile applications other than apparel purposes.
\end{abstract}

Keywords: Alkali extraction, Cornhusk fibres, Enzyme treatment, Bleaching, Physio-chemical properties

\section{Introduction}

Accumulation of unmanaged agro-waste especially from the developing counties has an increased environmental concern. Recycling of such wastes into sustainable, energy efficient textile materials is a viable solution for the problem of pollution and natural resource conservation for future generations. Utilizing cornhusk for textile applications could become a major breakthrough in this direction. Many other fibres have been extracted from different plants like milkweed stems, water hyacinth etc. and by products of some plants like bagasse which are being applied in various fields of textiles. Few studies have been carried out earlier also to utilize cornhusk for extraction of fibres. Reddy \& Yang (2007) extracted natural cellulose fibres from cornhusk and claimed that the extracted fibres had properties between cotton and linen. In another study, Y1lmaz (2013) studied the effect of chemical parameters like alkali concentration and treatment time on the properties of extracted cornhusk fibres. Yllmaz, N.D et al. (2014) also investigated the effect of xylanase enzyme on the mechanical properties of fibres extracted from fresh and dried cornhusk. The present study also aimed at extraction of fibres from cornhusk by treating it with alkali, enzyme and bleach. The extracted cornhusk fibres were then assessed for various physico-chemical parameters to find out their suitability for various textile applications.

\section{Material And Methods}

Cornhusk was collected from District Sonepat, Haryana with the help of Directorate of Maize Research, Pusa Campus, New Delhi. The husk was cleaned, dried and stored.

2.1 Extraction of cornhusk fibres: The extraction of fibres from cornhusk was carried out by step-wise treatment with alkali, enzyme and bleach.

\subsubsection{Optimization of treatment parameters for alkali extraction}

Firstly, the cornhusk was treated with alkali solution for partial delignification. Effect of different parameters like concentration of alkali, temperature and time was studied. The experiments were conducted to study;

- Effect of temperature: In order to optimize the temperature, alkali treatment was carried out at different temperatures, keeping all the other parameters constant. The fibres obtained were then evaluated for various characteristics. The alkali treatment was carried out as per the following conditions:-

Table. 1: Effect of temperature on extraction

\begin{tabular}{|l|c|l|}
\hline Sodium hydroxide $(\mathrm{NaOH})$ & $:$ & $3 \mathrm{~g} / 1$ \\
\hline MLR & $:$ & $1: 40$ \\
\hline Temperature & $:$ & $55-60^{\circ} \mathrm{C}, 70-75^{\circ} \mathrm{C}, 85-90^{\circ} \mathrm{C}, 98-100^{\circ} \mathrm{C}$ \\
\hline Time & $:$ & 60 minutes \\
\hline
\end{tabular}


After the treatment, extracted fibres were rinsed in water thoroughly (3-5 washes were sufficient) and then neutralized. The fibres obtained were then evaluated for various characteristics.

- Effect of alkali concentration and time: Once the optimum temperature was obtained, the alkali concentration and treatment time was optimized. The cornhusk was treated with four concentrations of sodium hydroxide .The treatment time was kept at 60 minutes, 90 minutes and 120 minutes.

Table. 2: Effect of time on extraction

\begin{tabular}{|l|l|l|}
\hline Sodium hydroxide $(\mathrm{NaOH})$ & $:$ & $2 \mathrm{~g} / \mathrm{l}, 3 \mathrm{~g} / \mathrm{l}, 4 \mathrm{~g} / \mathrm{l}$ and $5 \mathrm{~g} / \mathrm{l}$ \\
\hline MLR & $:$ & $1: 40$ \\
\hline Temperature & $:$ & $98-100^{\circ} \mathrm{C}$ \\
\hline Time & $:$ & 60,90 and 120 minutes \\
\hline
\end{tabular}

The fibres obtained were then evaluated for various characteristics. After the finalization of alkali formulation to be used for extraction of cornhusk fibres, the fibres were treated with enzyme to increase their fineness.

\subsubsection{Optimization of parameters for enzyme treatment}

- Effect of concentration of enzyme and treatment time: The extracted fibres were treated with three different concentrations of enzyme i.e. $1 \%, 3 \%, 5 \%$ (owf).The time taken for treatment was 30 minutes, 60 minutes and 90 minutes. The different experiments were carried out as per the following plan:

Table.3: Effect of enzyme on alkali extracted cornhusk fibres

\begin{tabular}{|l|l|l|}
\hline Enzyme & $:$ & $1 \%, 3 \%, 5 \%$ (owf) \\
\hline pH & $:$ & $8-9$ (as per the supplier's specifications) \\
\hline MLR & $:$ & $1: 20$ \\
\hline Temperature & $:$ & $55-60^{\circ} \mathrm{C}$ (as per the supplier's specifications) \\
\hline Time & $:$ & 30,60 and 90 minutes \\
\hline
\end{tabular}

The fibres obtained were then evaluated for various characteristics.

\subsubsection{Optimization of recipe for bleaching of extracted cornhusk fibres}

Cornhusk fibres obtained from the combined chemical and enzymatic extraction were yellowish in colour; hence they were bleached using hydrogen peroxide. The optimum $\mathrm{pH}$ and temperature of this bleach already established for cellulosic fibres was used for cornhusk fibres also.

- Effect of concentration of bleach and treatment time: The concentration of bleach and treatment time was optimized. Other auxiliaries were added as per the formulation used for cellulosic fibres. The experiments were conducted as follows:

Table. 4: Effect of concentration of bleach and treatment time onalkali extracted cornhusk fibres

\begin{tabular}{|l|l|l|}
\hline Hydrogen peroxide & $:$ & $1 \mathrm{~g} / \mathrm{l}, 2 \mathrm{~g} / \mathrm{l}, 3 \mathrm{~g} / \mathrm{l}$ \\
\hline Stabiliser (Sodium silicate) & $:$ & $3 \mathrm{~g} / \mathrm{l}$ \\
\hline Sequestering agent (EDTA) & $:$ & $.5 \mathrm{~g} / \mathrm{l}$ \\
\hline Sodium hydroxide: & $:$ & $0.5 \mathrm{~g} / \mathrm{l}$ \\
\hline Sodium carbonate $\mathrm{pH} 10-11$ & $:$ & $1.8 \mathrm{~g} / \mathrm{l}$ \\
\hline MLR & $:$ & $1: 30$ \\
\hline Temperature & $:$ & $85-90^{\circ} \mathrm{C}$ \\
\hline Time & $:$ & $\begin{array}{l}30 \text { minutes, } 60 \text { minutes, } 90 \\
\text { minutes }\end{array}$ \\
\hline
\end{tabular}

After bleaching the fibres were washed, neutralised and dried at ambient conditions. The bleached fibres were tested to evaluate the effect of bleaching on the colour, fineness and strength of the fibres.

\subsection{Estimation of composition of cornhusk fibres}

- Cellulose, hemicelluloses (pentosans) and lignin content: The composition analysis of cornhusk fibres was done in accordance with TAPPI standards at Cellulose and Pulp Division, Forest Research institute, Dehradun, Uttrakhand.

- Ash content: It was determined according to I.S - 199-1989 standard method 
- Wax content: It was determined in accordance with I.S-199-1973 standard method.

\section{Results And Discussion}

Extraction of cornhusk fibres: Cornhusk was collected from fields, cleaned and dried. Then it was subjected to various treatments.

\subsection{Alkali Treatment of Cornhusk}

Effect of temperature: The first parameter to be standardized was temperature. Alkali treatment of cornhusk was carried out at different temperatures with $3 \mathrm{~g} / \mathrm{l}$ solution of sodium hydroxide taking MLR of 1:40 for 60 minutes. Temperatures taken were room temperature, $55-60^{\circ} \mathrm{C}, 70-75^{\circ} \mathrm{C}, 85-90^{\circ} \mathrm{C}$ and $98-100^{\circ} \mathrm{C}$. The husk did not disintegrate at all till $60^{\circ} \mathrm{C}$ while at $75^{\circ} \mathrm{C}$; slight opening of husk into broad ribbon like strands could be seen. Further, it was also observed that husk got disintegrated at $85-90^{\circ} \mathrm{C}$ but not completely, some of the husk remained intact which might be due to the variation in the quality of the husk of inner and outer layers or lower and upper portions of husk.

The result obtained at boiling temperature was satisfactory as complete husk got disintegrated and fibres were obtained which were yellowish in colour having fineness of 130 denier with tenacity $1.51 \mathrm{~g} / \mathrm{d}$. The result was in accordance with the findings of other researchers' studies, i.e. Reddy and Yang (2007) and Yilmaz (2012), who have also reported extraction of fibres from cornhusk at boil.

Effect of alkali concentration and time: After optimizing temperature, effect of alkali concentration and treatment time on extraction of fibres from cornhusk was studied simultaneously. Cornhusk was treated with four concentrations of sodium hydroxide i.e. $2 \mathrm{~g} / \mathrm{l}, 3 \mathrm{~g} / \mathrm{l}, 4 \mathrm{~g} / \mathrm{l}$ and $5 \mathrm{~g} / \mathrm{l}$. The treatment time was kept at 60 minutes, 90 minutes and 120 minutes while temperature was kept at 98-100 $\mathrm{C}$ and MLR was taken as 1:40.

The weight loss after various treatments was calculated. Table 1 shows the loss in weight of cornhusk after alkali treatment with different concentrations and treatment time. Loss in weight was calculated to estimate the quantity of fibres obtained after alkali treatment.

As the concentration of sodium hydroxide increased from $2 \mathrm{~g} / \mathrm{l}$ to $5 \mathrm{~g} / \mathrm{l}$, there was a sharp increase in loss of weight after $2 \mathrm{~g} / \mathrm{l}$. The cornhusk did not disintegrate at all till 60 minutes while at longer treatment time slight separation of fibres had started. As the concentration increased to $3 \mathrm{~g} / \mathrm{l}$, there was a marked increase in the weight loss. The weight loss also increased with increase in time from $66.8 \%$ at 60 minutes to $72 \%$ at 120 minutes.

Table 6: Effect of sodium hydroxide concentration on weight loss in cornhusk

\begin{tabular}{|l|l|l|l|l|}
\hline \multirow{5}{*}{$\begin{array}{l}\text { Time } \\
\text { in Minutes }\end{array}$} & \multicolumn{5}{|l|}{ Concentration of sodium hydroxide solution } \\
\cline { 2 - 5 } & $\mathbf{2}$ g/l & $\mathbf{3}$ g/l & $\mathbf{4}$ g/l & $\mathbf{5}$ g/l \\
\hline 60 & 10.74 & 66.84 & 75.54 & 76.92 \\
\hline 90 & 33.24 & 68.18 & 76.08 & 77.12 \\
\hline 120 & 38.75 & 72.97 & 78.62 & 84.15 \\
\hline Temperature: $98-100^{\circ} \mathrm{C}$, MLR: $1: 40$ & \multicolumn{5}{|l}{} \\
\hline
\end{tabular}

The fibres obtained with alkalization by 3-5 g/l sodium hydroxide solution for 60,90 and 120 minutes were then evaluated for bundle strength and fineness. Table 2 clearly indicates that the strength of extracted fibres did not vary significantly at most of the treatments, but as the concentration of $\mathrm{NaOH}$ solution increased from $3 \mathrm{~g} / \mathrm{l}$ to $4 \mathrm{~g} / \mathrm{l}$, there was an improvement in the bundle strength of fibres at all treatment durations. The concentration of alkali seems to be more influencing factor as compared to treatment time; as increase in concentration to $5 \mathrm{~g} / \mathrm{l}$ caused more reduction in strength of fibres at all the durations. The fineness of fibres increased with increase in sodium hydroxide concentration and treatment time.

Table 7: Effect of alkali concentration and time on fibre fineness and strength

\begin{tabular}{|c|c|c|c|c|c|c|}
\hline \multirow{3}{*}{$\begin{array}{l}\text { Time } \\
\text { ( Minutes) }\end{array}$} & \multicolumn{6}{|c|}{ Concentration of sodium hydroxide solution } \\
\hline & \multicolumn{2}{|l|}{$3 \mathrm{~g} / \mathrm{l}$} & \multicolumn{2}{|l|}{$4 \mathrm{~g} / \mathrm{l}$} & \multicolumn{2}{|l|}{$5 g / 1$} \\
\hline & $\begin{array}{l}\text { Bundle strength } \\
\text { (g/denier) }\end{array}$ & $\begin{array}{l}\text { Fineness } \\
\text { (Denier) }\end{array}$ & $\begin{array}{l}\text { Bundle strength } \\
\text { (g/denier) }\end{array}$ & $\begin{array}{l}\text { Fineness } \\
\text { (Denier) }\end{array}$ & $\begin{array}{l}\text { Bundle strength } \\
\text { (g/denier) }\end{array}$ & $\begin{array}{l}\text { Fineness } \\
\text { (Denier) }\end{array}$ \\
\hline 60 & 1.37 & 160 & 1.59 & 130 & 1.15 & 106 \\
\hline 90 & 1.35 & 152 & 1.55 & 125 & 1.03 & 98 \\
\hline 120 & 1.22 & 145 & 1.32 & 117 & 0.90 & 88 \\
\hline
\end{tabular}


The fibres obtained with $4 \mathrm{~g} / \mathrm{l}$ of sodium hydroxide solution with a treatment time of 60 minutes were optimum in terms of strength and fineness i.e. $1.59 \mathrm{~g} /$ denier and 130 denier respectively. Hence a concentration of $4 \mathrm{~g} / \mathrm{l}$ sodium hydroxide with a treatment time of 60 minutes at a material to liquor ratio of 1:40 and a temperature of $98-100^{\circ} \mathrm{C}$ was finalized for alkalization of cornhusk to extract fibres.

As the fibres extracted with sodium hydroxide were coarse and brittle, they were given an enzyme treatment to overcome these drawbacks. Reddy \& Yang (2007) reported that alkali treatment alone yields relatively coarse and lower quality fibre bundles. They also indicated that only enzyme treatment is not sufficient to obtain optimum results as enzymes are unable to breakdown the outside layer of protective material on cornhusk completely.

\subsection{Enzyme Treatment of Alkali Extracted Fibres}

Effect of concentration of Enzyme and treatment time: Table 8 clearly indicates a positive impact of increasing concentration of enzyme on the bundle strength of fibres for a treatment time of 30 minutes. While increasing the treatment time more than 60 minutes led to decrease in bundle strength of fibres. The fineness of fibres increased with increase in concentration and treatment time both. Enzyme treated fibres showed better strength as compared to untreated fibres at each concentration for treatment durations of 30 and 60 minutes though the increase in strength was not much at 60 minutes. Yilmaz et al (2012) also reported that xylanase treated cornhusk fibres had greater breaking tenacity $(9.47 \mathrm{cN} /$ tex $)$ as compared to the untreated fibres $(9.23 \mathrm{cN} /$ tex $)$.

Table 8: Effect of concentration of Pulpzyme HC and treatment time on alkali extracted cornhusk fibres

\begin{tabular}{|l|l|l|l|l|l|l|}
\hline $\begin{array}{l}\text { Time } \\
\text { ( Minutes) }\end{array}$ & \multicolumn{6}{l}{ Concentration of Pulpzyme HC (\% owf) } \\
\cline { 2 - 7 } & $\begin{array}{l}\text { 1\% } \% \\
\text { Bundle strength } \\
\text { (g/denier) }\end{array}$ & $\begin{array}{l}\text { Fineness } \\
\text { (Denier) }\end{array}$ & $\begin{array}{l}\text { Bundle strength } \\
\text { (g/denier) }\end{array}$ & $\begin{array}{l}\text { Fineness } \\
\text { (Denier) }\end{array}$ & $\begin{array}{l}\text { Bundle strength } \\
\text { (g/denier) }\end{array}$ & $\begin{array}{l}\text { Fineness } \\
\text { (Denier) }\end{array}$ \\
\hline 30 & 1.41 & 115 & 1.51 & 108 & 1.56 & 97 \\
\hline 60 & 1.31 & 111 & 1.32 & 103 & 1.37 & 95 \\
\hline 90 & 1.03 & 109 & 1.11 & 99 & 0.89 & 94 \\
\hline Constant Parameters: pH: 8-9, Temperature: 55 -60 ${ }^{\circ} \mathrm{C}$, MLR: 1:20 \\
\hline
\end{tabular}

The fibres were treated with three concentrations (1\%, $2 \%$ and $3 \%$ owf) of Pulpzyme HC for three treatment times (30,60 and 90 minutes) while $\mathrm{pH}$ and temperature was taken as per the specifications of the supplier. The MLR was taken as 1:20. Treatment with Pulpzyme HC resulted in increase in strength of the fibres at treatment times of 30 and 60 minutes but at 90 minutes the strength got lowered. Probably, the bundle strength got affected adversely at longer treatment time due to cellulose backbone being attacked along with the hemicelluloses and lignin. The strength of the fibres improved with increase in concentration of enzyme, which may be due to removal of hemicelluloses and hence improved flexibility of fibres. Though any remarkable change in strength of the fibres was not observed but fineness improved a lot with enzyme treatment. Moreover, the texture of cornhusk fibres got softened. Considering the results given in Table 3, the treatment was optimized at 5\% Pulpzyme $\mathrm{HC}$ (owf) for 30 minutes with $\mathrm{pH}$ at $8-9$ and temperature between $55-60^{\circ} \mathrm{C}$ as the fibres had highest bundle strength i.e. $1.56 \mathrm{~g} / \mathrm{d}$ and optimum fineness i.e. 97 denier.

\subsection{Bleaching of Extracted Cornhusk Fibres}

As the fibres extracted with alkali and enzyme, were yellowish in colour, bleaching treatment with hydrogen peroxide was given. The bleaching was carried out at three concentrations i.e. $1 \mathrm{~g} / \mathrm{l}, 2 \mathrm{~g} / \mathrm{l}$ and $3 \mathrm{~g} / \mathrm{l}$ of hydrogen peroxide for 30, 60 and 90 minutes at a temperature of $85-90^{\circ} \mathrm{C}$, MLR: $1: 30$ and $\mathrm{pH}: 10.5$.The optimization of the bleaching treatment was done in terms of whiteness index and bundle strength of treated fibres.

Effect of concentration of hydrogen peroxide and treatment time:Table 9 shows the bundle strength, fineness and whiteness index of bleached fibres. It is obvious from the results depicted in the Table that the fibres did not bleach to white as the whiteness index is only 69, even for the most vigorous treatment i.e. $3 \mathrm{~g} / \mathrm{l}$ hydrogen peroxide for 90 minutes. In spite of bleaching the fibres with such higher concentration of hydrogen peroxide, the fibres did not leave their inherent yellowish tinge. Interestingly, Reddy and Yang (2007) have reported to obtain whiteness index of 98 by bleaching cornhusk fibres with $3 \mathrm{~g} / \mathrm{l}$ hydrogen peroxide at $90^{\circ} \mathrm{C}$ for 60 minutes. In another study Salam et al (2007) have claimed to bleach cornhusk fibres to a CIE whiteness index of 74 after giving a delignification pre-treatment with sodium sulphite. 
Table 9: Effect of concentration of hydrogen peroxide and treatment time on enzyme treated cornhusk fibres

\begin{tabular}{|c|c|c|c|c|c|c|c|c|c|}
\hline \multirow{3}{*}{$\begin{array}{l}\text { Time } \\
\text { (Minutes) }\end{array}$} & \multicolumn{9}{|c|}{ Concentration of hydrogen peroxide } \\
\hline & \multicolumn{3}{|l|}{ 1g/l } & \multicolumn{3}{|l|}{$2 \mathrm{~g} / \mathrm{l}$} & \multicolumn{3}{|l|}{$3 \mathrm{~g} / \mathrm{l}$} \\
\hline & $\begin{array}{l}\text { Bundle } \\
\text { strength } \\
\text { (g/denier) }\end{array}$ & $\begin{array}{l}\text { Fineness } \\
\text { (Denier) }\end{array}$ & W.I & $\begin{array}{l}\text { Bundle } \\
\text { strength } \\
\text { (g/denier) }\end{array}$ & $\begin{array}{l}\text { Fineness } \\
\text { (Denier) }\end{array}$ & W.I & $\begin{array}{l}\text { Bundle strength } \\
\text { (g/denier) }\end{array}$ & $\begin{array}{l}\text { Fineness } \\
\text { (Denier) }\end{array}$ & W.I \\
\hline 30 & 1.46 & 95 & 49 & 1.40 & 90 & 55 & 1.20 & 82 & 59 \\
\hline 60 & 1.33 & 92 & 51 & 1.33 & 86 & 60 & 1.00 & 78 & 67 \\
\hline 90 & 1.10 & 87 & 54 & 0.94 & 83 & 63 & 0.89 & 74 & 69 \\
\hline \multicolumn{10}{|c|}{ Constant parameters: Temp: $85-90^{\circ} \mathrm{C}, \mathrm{MLR}: 1: 30, \mathrm{pH}: 10.5$} \\
\hline \multicolumn{10}{|c|}{$\begin{array}{l}\text { Control sample ( Alkali and enzyme treated fibres): Whiteness Index: 44; } \\
\text { Bundle strength: } 1.52 \mathrm{~g} / \text { denier; Fineness: } 97 \text { Denier }\end{array}$} \\
\hline
\end{tabular}

The bundle strength of fibres reduced considerably with increase in concentration of hydrogen peroxide and treatment time. Up to $2 \mathrm{~g} / \mathrm{l}$ concentration of hydrogen peroxide, not much lowering of strength had occurred but at higher concentration the loss in strength was quite high. Considering all the three parameters, concentration of $2 \mathrm{~g} / \mathrm{l}$ hydrogen peroxide for 60 minutes treatment time was selected, as the fibres had optimum properties at this combination i.e. $1.33 \mathrm{~g} /$ denier bundle strength, fineness of 86 deniers and whiteness index of 60. The softener, DPT 080 (Resil) was applied to the fibres after bleaching, at the concentration of $1 \%$ owf as per the specifications mentioned by the supplier. The application of softener resulted in smooth handle and it also made the opening of fibres much easier.

\subsection{Estimation of Composition of Extracted Cornhusk Fibres}

Firstly, the extracted cornhusk fibres were analyzed for their composition, as the properties of any fibre are governed by its composition in principal. Afterwards, the physical properties like length, fineness, bundle strength and elongation at break were determined.

Cellulose, hemicelluloses (pentosans) and lignin content: All the three constituents were estimated at three stages of fibre extraction i.e. after alkali extraction, after enzyme treatment and after bleaching. These constituents were also determined for original dried cornhusk.

Table 10: Composition of cornhusk and cornhusk fibres at different stages of extraction

\begin{tabular}{|l|l|l|l|l|}
\hline S.No. & Specimen & $\begin{array}{l}\text { Cellulose } \\
(\boldsymbol{\%})\end{array}$ & $\begin{array}{l}\text { Hemicelluloses } \\
(\text { Pentosans \%) }\end{array}$ & $\begin{array}{l}\text { Lignin } \\
(\boldsymbol{\%})\end{array}$ \\
\hline 1. & Cornhusk & 49.56 & 21.24 & 13 \\
\hline 2. & $\begin{array}{l}\text { Alkali extracted cornhusk } \\
\text { fibres }\end{array}$ & 60.84 & 18.97 & 10 \\
\hline 3. & $\begin{array}{l}\text { Enzyme treated cornhusk } \\
\text { fibres }\end{array}$ & 71.05 & 14.55 & 09 \\
\hline 4. & Bleached cornhusk fibres & 76.0 & 11.43 & 7.5 \\
\hline
\end{tabular}

As evident from Table 10, the cellulose proportion in cornhusk was the lowest, i.e. $49.56 \%$ while in cornhusk fibres, it increased gradually after each step of extraction i.e. alkali treatment, enzyme treatment and bleaching treatment. The reason for increase in cellulose proportion could be attributed to removal of hemicelluloses, lignin and other impurities by sodium hydroxide, pulpzyme and hydrogen peroxide.

Xylanase opens up the hemicelluloses structure containing bound lignin and facilitates the removal of precipitated lignin-carbohydrate complexes prior to bleaching. By using xylanase, it is possible to wash out more lignin from the ligno cellulosic material and make the pulp more susceptible to bleaching chemicals (www.novozymes.com). Hydrogen peroxide bleaching also leads to removal of lignin from fibres and makes them bright.

Wax content:The wax content of cornhusk fibres was found to be $0.25 \%$. The low percentage of wax content in cornhusk fibres may be because of its treatment with alkali during extraction which removes the wax.

Ash content:Extracted cornhusk fibres have an ash content of $0.34 \%$.

\section{Conclusion}

A concentration of $4 \mathrm{~g} / \mathrm{l}$ sodium hydroxide with a treatment time of 60 minutes at a material to liquor ratio of 1:40 and a temperature of $98-100^{\circ} \mathrm{C}$ was finalized for alkalization of cornhusk to extract fibres as the fibres obtained in these conditions were optimum in terms of strength and fineness i.e. $1.59 \mathrm{~g} / \mathrm{denier}$ and 130 deniers respectively. . The enzyme treatment was optimized at 5\% Pulpzyme HC (owf) for 30 minutes with $\mathrm{pH}$ at 8-9 and temperature between $55-60^{\circ} \mathrm{C}$ as the fibres had highest bundle strength i.e. $1.56 \mathrm{~g} / \mathrm{d}$ and optimum fineness i.e. 97 denier. Concentration of $2 \mathrm{~g} / \mathrm{l}$ hydrogen peroxide for 60 minutes treatment time was found to be most suitable, as the fibres had optimum properties at this combination i.e. $1.33 \mathrm{~g} /$ denier bundle strength, 
fineness of 86 deniers and whiteness index of 60 . Bundle strength of cornhusk fibres was lower than other lignocellulosic fibres which can be compensated by blending with other suitable fibres. As the fibres obtained from cornhusk are not suitable for apparel purposes due to their coarse and harsh nature, their application for different segments of technical textiles could be looked upon. Extensive research needs to be carried out for achieving this milestone of using cornhusk fibres successfully in textile applications.

\section{References}

[1]. Reddy, N., \& Yang, Y. (2005). Long natural cellulosic fibers from cornhusks: structure and properties. AATCC Review, 5(7).

[2]. Reddy, N., \& Yang, Y. (2005). Properties and potential applications of natural cellulose fibers from cornhusks. Green Chemistry, 7(4), 190-195.

[3]. Yilmaz, N. D. (2013). Effect of chemical extraction parameters on corn husk fibres characteristics. Indian Journal of Fibre \& Textile Research, 38 (1), 29-34.

[4]. Yılmaz, N. D., Calıșkan, E. ,\&Yılmaz, K. (2014). Effect of xylanase enzyme on mechanical properties of fibres extracted from undried and dried corn husks. Indian Journal of Fibre \& Textile Research, 39 (1), 60-64.

[5]. Kaushik, V. K., Kumar, A., \&Kalia, S. (2012). Effect of mercerization and benzoyl peroxide treatment on morphology, thermal stability and crystallinity of sisal fibers. International Journal of Textile Science, 1(6), 101-105.

[6]. Barl, B., Biliaderis, C. G., \& Murray, E. D. (1986). Effect of chemical pretreatments on the thermal degradation of corn husk lignocellulosics. Journal of Agricultural and Food Chemistry, 34(6), 1019-1024.

[7]. Salam, A., Reddy, N., \& Yang, Y. (2007). Bleaching of kenaf and cornhusk fibers. Industrial \& Engineering Chemistry Research, 46(5), 1452-1458.

[8]. Pandey, A. (Ed.). (2011). Biofuels: alternative feedstocks and conversion processes. Academic Press.

[9]. Franck, R.R., (2005), Bast and Other Plant Fibres, Cambridge England: Woodhead Publishing in textiles, 331-339, 322-327, 228-242.

[10]. www.icdd.com ( Last accessed on 21.09.2015)

[11]. www.novozymes.com( Last accessed on 27.08.2015) 